\title{
OTES ON THE GREEN FROG AND HE MINK FROG IN MANITOBA
}

ER TAYLOR, P.O. Box 59, Pinawa, Manitoba. RoE 1 L0

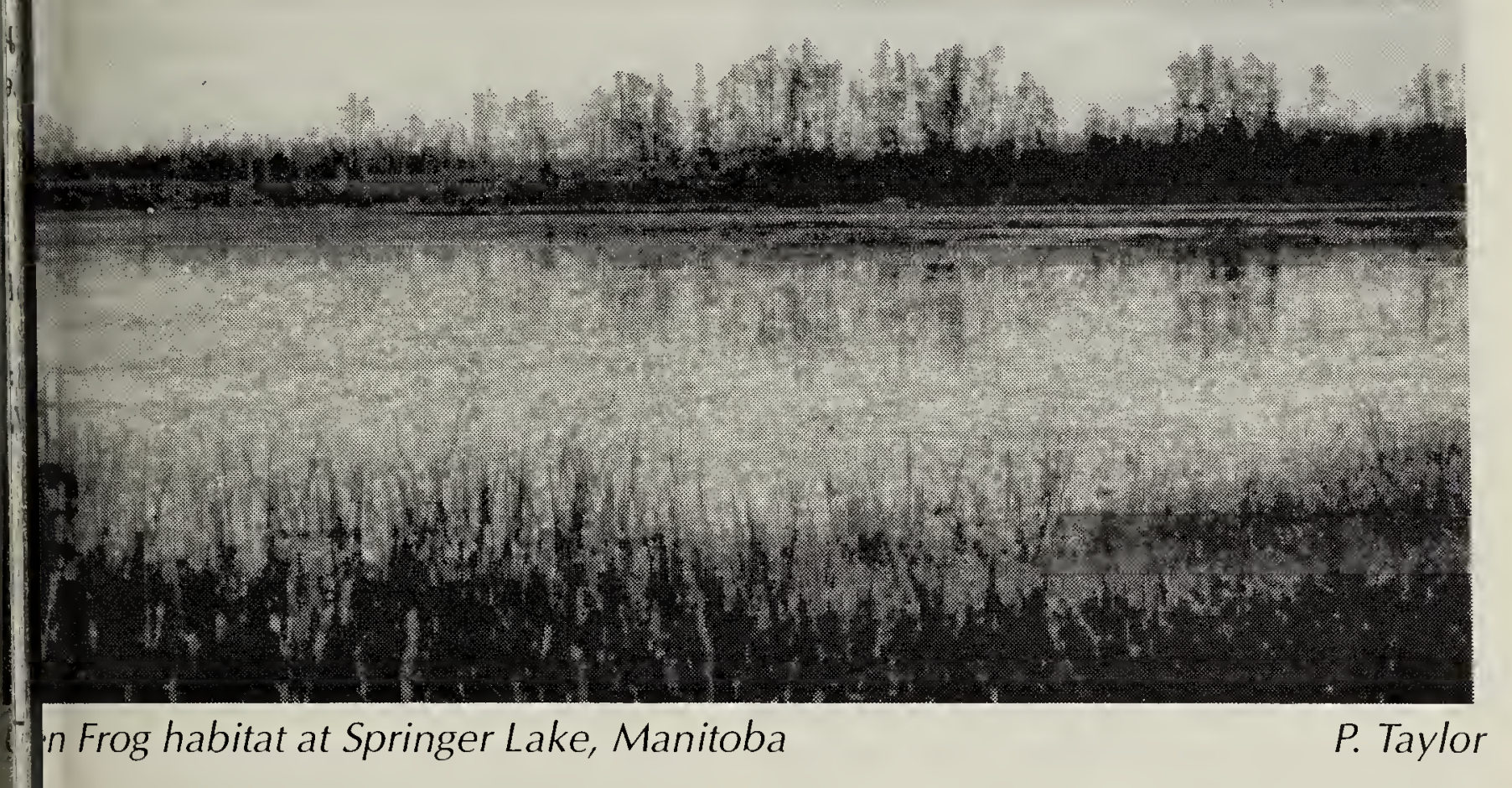

e Green Frog [Rana clamitans nota (Rafinesque)] and the Mink $[R$. septentrionalis Baird] are both $y$ aquatic species that reach the ern limits of their ranges in leastern Manitoba.' 2356 Both are mmon in the province. This paper ts a sound record of the Green Frog of its previously recorded Manitoba and additional sight and sound ds of the Mink Frog.

ere are only three Manitoba mens of the Green Frog, all from eshell Provincial Park (P.P.): two at George Lake by S. Criddle, 7 ber 1936, and one east of Pointe du by R.K. Stewart-Hay, 20 August - Logier and Toner cite an additional ty, Caddy Lake (also in Whiteshell ased on correspondence with R.W. 7, and this is included on Preston's ution map.

re are many more records of the Frog than the Green Frog in
Manitoba, all in or near Whiteshell P.P. ${ }^{6}$ Early confusion as to the status of this species in the province was clarified by Cook, who collected 12 specimens and examined others, and Preston has mapped seven known localities.'

While conducting a Breeding Bird Survey at Springer Lake, Nopiming P.P. $\left(50^{\circ} 32^{\prime} \mathrm{N}, 95^{\circ} 28^{\prime} \mathrm{W}\right)$, at $0500 \mathrm{~h}$ on 23 June 1989 , I heard a familiar and unmistakable "clung," the territorial call of a male Green Frog. It was no longer calling at 0930, after the bird survey was complete, but calls were heard again on three subsequent visits that summer: 0600 to 0700 h 25 June; 1915 to 2000 h 29 June; 2130 to $2200 \mathrm{~h} 31$ July. It is likely that the same individual was heard on each occasion, because the calls issued from the same point in the lake, close to the eastern shore of a bay near Provincial Road (P.R.) 314. The calls were clearly audible from 300 to $500 \mathrm{~m}$ across the bay. 


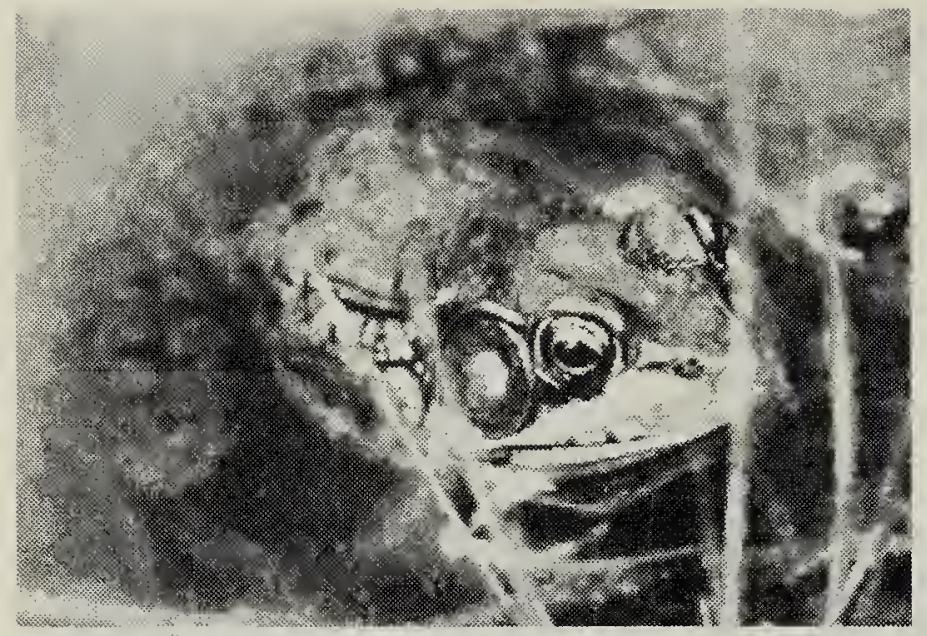

Green Frog in New Brunswick P. Taylor

These observations confirm the continued, albeit perhaps tenuous existence of the Green Frog in Manitoba, and May indicate its territorial behaviour in the province (for an account of the territorial nature of this frog, see Jenssen and Preston, and references therein ${ }^{4}$ ). The calling dates fall within the expected breeding season. The locality is about $30 \mathrm{~km}$ north of the previous specimen localities, George Lake and Pointe du Bois. Springer Lake lies in a rocky, forested area at the edge of the Maskwa burn, site of a major forest fire in September 1983. The bay where the frog was heard is bordered with emergent vegetation (mainly sedges and cattails), and Yellow Pond-lilies (Nuphar variegatum) are numerous in the open water.

Small numbers of Mink Frogs were also heard in the same bay on each visit. On 25 June, they were heard at five additional locations southwest of Springer Lake. Three of these locations were along Peterson Creek, which drains Springer Lake into the Oiseau (Bird) River. The Oiseau River flows in turn into Lac du Bonnet on the Winnipeg River. From the junction of P.R. 314 and 315, the three locations were $4.9 \mathrm{~km}$ northeast, $2.5 \mathrm{~km}$ northeast, and $4.2 \mathrm{~km}$ southwest. The fourth was a beaver pond east of P.R. 315, $3.0 \mathrm{~km}$ northeast of Poplar Bay campground. The fifth was the eastern extremity of Pinawa Lake, just northwest of the junction of P.R. 313 and $315\left(50^{\circ} 20^{\prime} \mathrm{N}, 95^{\circ} 47^{\prime} \mathrm{W}\right)$. Poplar Bay and Pinawa Lake are both arms of Lac du Bonnet. All these localities lie si within the northwestern range limito Mink Frog as estimated by Preston.

The Mink Frog's call is less distin than that of the Green Frog, usua triple cluck that suggests the phrase ber duck." This resembles the call $\mathrm{c}$ Wood Frog [R. sy/vatica LeConte], w is abundant in much of Manitoba, in ing the Whiteshell - Nopiming re: Although the Wood Frog chorus early spring phenomenon, some dividuals call sporadically in midmer. At the first of the Peterson localities listed above, identificatio calling Mink Frogs was confirmed b cellent views of four individuals $s$ : ming and floating in the slow, dark $w$ of the creek. They were readily iden by their size (comparable to a Lec Frog, R. pipiens Schreber) and $\xi$ colour with irregular dark mottling.

I thank W. B. Preston for encou ment and helpful comments.

1 COOK, F.R. 1963. The rediscov the Mink Frog in Manitoba. Can. Fiell 77:129-130.

2 COOK, F.R. 1984. Introducti Canadian reptiles and amphibians. Mus. Nat. Sci., Ottawa. 200 pp.

${ }^{3}$ HEDEEN, S.E. 1986. The sol geographic limit of the Mink Frog, septentrionalis. Copeia (No. 1) 239-؛

${ }^{4}$ JENSSEN, T.A. and W.B. PRES 1968. Behavioral responses of the Green Frog, Rana clamitans, recorded call. Herpetologica 24:181

${ }^{5}$ LOGIER, E.B.S. and G.C. TO 1961. Check list of the amphibian reptiles of Canada and Alaska. Contr Life Sci. Div., Roy. Ont. Mus., Toron pp.

6 PRESTON, W.B. 1982. The phibians and reptiles of Manitoba. Mus of Man and Nature, Winnipeg. 1 